\title{
De cativos a baleeiros: uma amizade indissolúvel entre dois africanos no outro lado do Atlântico (Itaparica, 1816-1886)
}

Wellington Castellucci Junior*

\section{RESUMO}

Este artigo aborda a trajetória de dois africanos baleeiros que viveram na Ilha de Itaparica no período oitocentista. Com base em fontes inéditas, o texto revela a chegada desses dois indivíduos à maior ilha da baía de Todos os Santos, o período de cativeiro, a conquista da liberdade e a vida de ambos como libertos. Empreendedores da baleação, esses dois africanos nagôs tornaram-se figuras proeminentes de Itaparica, sendo responsáveis pela libertação de outros cativos e pela melhoria das condiçóes de vida de pessoas que viveram no seu círculo de amizade e de negócios.

Palavras-chave: baleação; africanidade; liberdade; religiosidade.

\begin{abstract}
This paper discusses the biographies of two nineteenth-century African whalers who lived on the island of Itaparica. Based on unpublished sources, the paper narrates the arrival of these two individuals to the largest island of the Brazilian Todos os Santos Bay, the period of captivity, the conquest of freedom and their lives as freemen. As whaling entrepreneurs, these two Nago Africans became prominent figures in Itaparica, being responsible for the release of other captives and for improving the living conditions of those who lived within their circle of friendship and business.
\end{abstract}

Keywords: whaling; Africanness; freedom; religiosity.

Artigo recebido em 6 de junho de 2014 e aprovado para publicação em 27 de agosto.

* Doutor em História Social pela Universidade de São Paulo, e professor adjunto de História da Universidade Federal do Recôncavo da Bahia. Salvador, BA, Brasil. E-mail: wcastelluccijunior@gmail.com. 


\section{Introdução}

Os africanos Marcos Theodoro Pimentel e José Severo Martins Braga foram, certamente, os mais proeminentes libertos empreendedores que viveram e atravessaram o período oitocentista na Ilha de Itaparica. Além de terem constituído famílias, deixado herança e bens materiais para muitos deles e para alguns de seus conterrâneos, eles nos legaram vasta descendência e uma extraordinária história da escravidão e da liberdade no Brasil do século XIX. Após mais de cem anos do passamento de ambos, suas trajetórias começam a ser reconstituídas parcialmente. ${ }^{1}$ E agora, como fênix, eles saem dos empoeirados e deteriorados documentos arquivados, e às vezes quase perdidos, para novamente ganhar vida e mostrar um lado pouco obscuro da escravidão de africanos em terras brasileiras.

Por tudo o que esses dois africanos fizeram, viraram referência e, provavelmente, deixaram pessoas do seu tempo impressionadas com os seus feitos, a exemplo do africano liberto Francisco de Brito, um matador de baleias que, em 1871, quase morreu ao ser surpreendido por um cetáceo, o qual arremessou a sua baleeira longe, despedaçando-a, depois de ser arpoada por um de seus marinheiros. ${ }^{2}$

Ao longo de suas vidas, eles testemunharam quase tudo o que ocorrera nas últimas décadas da escravidão na ilha. Assistiram a alguns de seus camaradas comprarem a liberdade, com razoável grau de certeza souberam da existência de quilombos enfronhados nos manguezais de Itaparica, observaram tentativas de levantes escravos em apoio ao malês da capital, acompanharam a decadência de antigos senhores que, por séculos, ostentaram riqueza oriunda da rentável caça, desmancho e beneficiamento dos derivados de baleia mortas em águas da baía de Todos os Santos. ${ }^{3}$ Embora lamentassem em seus testamentos o fato de não terem conhecido os seus pais e, por isso, não os registrarem em seus documentos finais,

\footnotetext{
${ }^{1}$ A respeito de Marcos Theodoro Pimentel, o importante estudo realizado pela pesquisadora Lisa Earl Castillo revela as suas relaçóes de caráter religioso com o povo de santo do Terreiro Ilê Axé Opô Afonjá, localizado em Salvador. In: CASTILLO, Lisa Earl. Entre memória, mito e História. Viajantes transatlânticos da Casa Branca. p. 108-109. In: REIS, João José; AZEVEDO, Elciene (Org.). Escravidão e suas sombras. Salvador: Edufba, 2012. p. 65-110.

2 APB - SEÇÃO COLONIAL/PROVINCIAL. Correspondências recebidas da Secretaria de Polícia da Provincia da Bahia, maço 313942, Salvador, 1871. (Série Polícia).

${ }^{3}$ A respeito da formação de Quilombos em Itaparica, ver HABSBURGO, Maximiliano de. Bahia, 1860: esboço de viagem. Salvador: Fundação Cultural do Estado da Bahia, 1982. Os seguintes documentos: APB - SEÇÃO COLONIAL/PROVINCIAL. Correspondência da Câmara Municipal de Itaparica, maço 2420, Judiciário, Itaparica, 1829. (Série Presidência da Província). APB - SEÇÃO JUDICIÁRIA, PRESIDÊNCIA DA PROVÍNCIA. Freguesia do Santíssimo Sacramento de Itaparica, maço 2420, 28 ago. 1828. (Série Juízes). Sobre levantes escravos na Ilha: APB - SEÇÃO COLONIAL/PROVINCIAL. Juízes de Itaparica, 18281836. Itaparica, 1835. Maço 2419. APB - Seção Colonial/Provincial. Juízes de Itaparica, 1828-1836, Itaparica, 27 de janeiro de 1835. Maço 2419. A respeito da decadência das armaçóes de caça e desmancho de baleia da Ilha de Itaparica, ver: CASTELLUCCI JUNIOR, Wellington. Pescadores e baleeiros: a atividade da pesca da baleia nas últimas décadas do oitocentos. Itaparica: 1860-1888. In: Revista Afro-Ásia. CEAO - Centro de Estudos Afro-Orientais, UFBA, Salvador, BA, v. 33, p. 133-168, 2005.
} 
ambos demonstraram, na prática quotidiana, o quão importante fora a instituição família numa perspectiva muito mais ampla do que a noção de ascendência burguesa e eurocêntrica, amplamente difundida em seu tempo e posteriormente a eles.

Eles não foram malungos, mas em algum momento suas vidas foram cruzadas e eles construíram, em solo itaparicano, uma grandiosa e duradoura relação de amizade, de compadrio e de sociedade. Seus sentimentos de fraternidade e companheirismo, para com os seus conterrâneos, foram instrumentos essenciais para a afirmação de suas identidades, da religiosidade e construção de caminhos viáveis para a libertação e a sobrevivência de alguns deles no curso de suas histórias. Eles marcaram presença como sujeitos diferenciados em seu tempo. Para entender como tudo isso aconteceu, acompanhemos as suas pegadas, seus vestígios, com cautela, para sabermos como esses dois indivíduos saíram do cativeiro para lograr destaque em liberdade.

\section{Da África para Itaparica}

A primeira vez que José Severo Martins Braga figurou no universo discursivo da língua senhorial foi por meio de um registro oficial, o livro de assento de batismos, importante procedimento religioso e financeiro, rigorosamente controlado pelo governo metropolitano e pela Igreja Católica desde o início do tráfico de africanos para o Brasil. ${ }^{4}$ De acordo com essa fonte, ele nos apareceu simplesmente com o profético e bíblico nome de José, adulto, preto, uma necessária distinção de época feita pelo pároco para qualificá-lo como africano. Mas, nesse caso, todos os outros escravos também foram registrados como pretos, o que denota a vontade do vigário de classificar os escravos em geral com essa nomenclatura. Ao lado de outros sete africanos escravizados e de duas "crias" crioulas, de pessoas livres, de brancos e de outros negros, seu primeiro senhor, Isidoro Martins Braga, o batizaria na Matriz do Santíssimo Sacramento de Itaparica, juntamente com um dos seus filhos legítimos, numa tranquila manhã de algum dia e mês do ano de 1816, quando o pároco não precisou a data e nem apontou a sua idade aproximada. ${ }^{5}$

\footnotetext{
${ }^{4}$ Ver sobre isso, ALENCASTRO, Luiz Felipe de. O trato dos viventes: Formação do Brasil no Atlântico Sul. Séculos XVI e XVII. 4 reimpressão. São Paulo: Companhia das Letras, 2000, p. 35-37. LARA, Silvia H. (Org.). Ordenaçôes Filipinas, Livro V. São Paulo: Companhia das Letras, 1999. ("Que os que tiverem escravos da Guiné que os batizem”, p. 308-9).

${ }^{5}$ Disponível em: <https://familysearch.org/pal:/MM9.3.1/TH-1-18354-12492-24?cc=2177272\&wc=M97YL5:24182851>. Livro de batismos da Freguesia do Santíssimo Sacramento de Itaparica, Livro B, 1815-1840, n. 1, folha 5. Acesso em: 20 jan. 2014. Na relação dos batizados naquele dia constam os seguintes escravos de propriedade de Isidoro Martins Braga: Constância, preta, adulta; Joaquim, preto, adulto; Justina, preta, filha natural de uma escrava; Rufino, preto, adulto; Francisco, preto, adulto; Aníbal, preto, adulto; Joáo, preto, adulto; Antônio, preto, filho natural da escrava Ana; e José, preto, adulto.
} 
José ingressou, portanto, no Brasil nos primeiros anos do Oitocentos, momento em que o tráfico de escravos ainda era legal e os acordos entre britânicos e a coroa portuguesa não haviam sido firmados. Tal pacto seria assinado em 1826, mas a lei brasileira que tornaria o tráfico ilegal só seria publicada em 1831.6 Assim, José chegou a Itaparica numa época de prosperidade e de expansão do tráfico de escravos para um Brasil que vivia momento de grandes transformaçôes políticas e econômicas desde a chegada da família real portuguesa em 1808. Atentos às pressóes exercidas pelos ingleses sobre a corte, traficantes e senhores escravocratas empreenderam, nessa fase, uma intensificação no comércio de escravizados, procedentes do continente africano, com vistas a suprir os mercados brasileiros antes do final do comércio de seres humanos.

Com efeito, entre o final do século XVIII e início do XIX, os demógrafos calculam que cerca de quatro quintos de todos os africanos foram transportados para o Novo Mundo. ${ }^{7} \mathrm{O}$ próprio Isidoro Martins Braga, senhor de José, adquiriu, com certa regularidade, "lotes" de escravos nesse tempo. Em 1820, no mesmo dia, ele batizou os "pretos" (africanos) Pedro, Rodolfo, e a "preta" Jesuína. ${ }^{8}$ Um ano depois, ele voltou a batizar, coletivamente, mais "pretos" africanos. Dessa vez foram Adam, Barnabé, Turíbio, Leal e Álvaro.? Mais tarde, chegariam mais africanos ao domínio desse senhor ilheense e, quando ele veio a falecer, no ano de 1847 , sua escravaria somava um total de 31 cativos, incluindo José nagô. ${ }^{10}$

Até então, pouca coisa haveria para se falar de José e nem conhecimento da sua suposta "naçáo" e provável idade se saberia, pois, entre o período da sua chegada até a década de 1830, as fontes silenciam e perdemos os seus rastros. Porém, em 1847, quando os bens do seu

\footnotetext{
${ }^{6}$ Dentre a vasta bibliografia a esse respeito, ver os seguintes autores: FLORENCE, Afonso Bandeira. Nem escravos, nem libertos: os "africanos livres" na Bahia. Cadernos do CEAS, Salvador, n. 121; FLORENCE, Afonso Bandeira. Entre o cativeiro e a emancipação: liberdade dos africanos livres no Brasil (1818-1864). Dissertação (Mestrado em História) - Faculdade de Filosofia e Ciências Humanas, Universidade Federal da Bahia, Salvador, 2002; BETHELL, Leslie. A abolição do comércio brasileiro de escravos. Brasília: Senado Federal, 2002; CONRAD, Robert Edgar. Os últimos anos de escravatura no Brasil: 1850-1888. Rio de Janeiro: Civilização Brasileira, 1978; CONRAD, Robert Edgar. Tumbeiros: o tráfico escravista para o Brasil. São Paulo: Brasiliense, 1985; KARASCH, Mary C. A vida dos escravos no Rio de Janeiro, 1808-1850. São Paulo: Companhia das Letras, 2000; RODRIGUES, Jaime. O infame comércio: propostas e experiências no final do tráfico de africanos para o Brasil (1808-1859). Campinas, SP: Editora da Universidade de Campinas/Cecult, 2000; GRAHAN, Richard. Nos tumbeiros mais uma vez? O comércio interprovincial de escravos no Brasil. Revista Afro-Ásia, Centro de Estudos Afro-orientais - Ceao/UFBA, Salvador, n. 27, p. 121-160, 2002; VERGER, Pierre. Fluxo e refluxo do tráfico de escravos entre o Golfo do Benin e a Bahia de Todos os Santos. Salvador: Corrupio, 1987.

${ }^{7}$ Dentre outros autores, ver KLEIN, Herbert S. Novas interpretaçóes do tráfico de escravos do Atlântico. Revista de História da USP, São Paulo, n. 120, p. 3-25, jan./jul. 1989. p. 17; KLEIN, Herbert. O tráfico de escravos no Atlântico. Ribeirão Preto, SP: Funpec, 2004; ELTIS, David; BEHRENDT, Stephen D.; RICHARDSON, David. A participação dos países da Europa e das Américas no tráfico transatlântico de escravos: novas evidências. Revista Afro-Ásia, Centro de Estudos Afro-Orientais - Ceao/UFBA, Salvador, BA, v. 24, p. 9-50, 2000; ELTIS, David; RICHARDSON, David. Os mercados de escravos africanos recém-chegados às Américas: padrôes de preços, 1673-1865. Topoi. Revista de História, Rio de Janeiro, p. 9-46, mar. 2003.

${ }^{8}$ LIVRO de Registros de Batismo, op. cit., p. 13.

${ }^{9}$ Ibid, p. 18.

10 APB - Seção Colonial/Provincial. Inventário de Isidoro Martins Braga. Itaparica, 1847. Doc: 4/1807/2278/15/99.
} 
primeiro senhor foram inventariados, José já estava aquinhoado a Severo Martins Braga, um dos filhos daquele senhor, que, no ato da sua avaliação, descreveu José como sendo um nagô de aproximadamente vinte e cinco anos de idade, do serviço da roça, sem moléstia, avaliado em quinhentos mil réis. ${ }^{11}$ A presunção de sua idade nesse ano sugere que José ingressou no Brasil bem jovem, quase uma criança. Mas a conta não fecha em seus aproximados vinte e cinco anos, pois se 31 anos haviam se passado após a sua chegada a Itaparica, seria difícil José ter apenas essa idade em 1847. Todavia, a percepção da sua jovialidade naquele ano pode explicar a sua longevidade e disposição em buscar a liberdade.

Durante aqueles anos, José trabalhou duro no trato da roça, de propriedade do seu senhor, desde a sua compra. Além disso, quase nada se sabe a respeito da sua vida nesse período. Mas, no curso daqueles anos de silêncio das fontes, quando estas o tornaram quase invisível, de algum modo José amadureceu, destacando-se no universo senhorial e na comunidade dos cativos.

Nas décadas seguintes ao seu ingresso no Brasil, ele passou a batizar outros africanos que, para este continente, foram trazidos e comprados pelo seu senhor e pessoas próximas a ele na Ilha de Itaparica. Provavelmente, se ele os apadrinhava, era porque gozava de algum respeito junto ao amo e aos seus. Como revelou Stuart Schwartz, um dos pioneiros no estudo do compadrio na Bahia escravista, essa instituição cumpria uma função importantíssima no âmago da relação senhor-escravo. Para ele, o compadrio de escravos se constituía num dos mais importantes organismos reguladores da relação entre ambos e da estabilidade nas áreas rurais. O ritual de batismo, portanto, era o momento de transição do "estrangeiro" recém-chegado para o mundo da comunidade dos cativos no outro lado do Atlântico. Os padrinhos cumpriam assim a função de "guiá-los" nesse novo mundo. Primeiro, introduzindo-os no universo da cristandade, depois, na disciplina do trabalho e da obediência. Finalmente, quem sabe, tirando-lhe do cativeiro e proporcionando-lhe a liberdade. Justamente por isso é que, na maioria absoluta dos registros de batismos, os senhores não figuram como padrinhos dos seus respectivos escravos, como foi o caso de José. Nas palavras de Schwartz, "se o vínculo do apadrinhamento era uma relação espiritual de proteção, o vínculo senhor-escravo era uma relação assimétrica de propriedade. Onde um representa socorro, o outro significa subserviência”. ${ }^{12}$ Com efeito, no decorrer das décadas seguintes, essa instituição

\footnotetext{
${ }^{11}$ APB - Seção Colonial/Provincial. Inventário de Isidoro Martins Braga.

${ }^{12}$ GUDEMAN, Stephen; SCHWARTZ. Stuart. Purgando o pecado original: compadrio e batismo de escravos na Bahia do século XVIII. In: REIS, João José (Org.). Escravidão e invenção da liberdade. Estudos sobre o negro no Brasil. São Paulo: Brasiliense, 1988. p. 42. Ver também, SCHWARTZ, Stuart B. Escravos, roceirose rebeldes. Bauru, SP: Edusc, 2001. Para uma pesquisa atualizada sobre batismo de africanos na Bahia, ver: SOARES, Carlos Eugenio Líbano. Instruídos na fé, batizados em pé: Batismo de africanos na Sé da Bahia na 1a metade do século XVIII. Revista Afro-Ásia, Centro de Estudos Afro-Orientais - Ceao/UFBA, Salvador, BA, v. 39, p. 79-113, 2010. O autor cita a importância dos batismos nas páginas 80 e 81 . Ver também SOARES, Carlos Eugenio Líbano. Sacramento ao pé do mar: Batismo de africanos na Freguesia da Conceição da Praia, Bahia. 1700-1751. Revista de História Comparada. Programa de Pós-graduação em História da Universidade Federal do Rio de Janeiro, Rio de Janeiro, v. 7, n. 2, p. 47-74, dez. 2013.
} 
tornar-se-ia de extrema importância na vida desses dois africanos e na emancipação de outros escravizados a eles ligados.

Assim, na manhã de $1^{\mathrm{o}}$ de janeiro de 1834 , diante de um pároco bem mais preocupado em registrar detalhadamente os assentos paroquiais, José batizou o africano Gonçalo, escravo de Francisco José da Costa, então genro do seu senhor. No mesmo dia e ano, ele, juntamente com o escravo Agostinho, batizou o cativo africano Antônio, também pertencente àquele senhor. ${ }^{13}$

Já em oito de novembro de 1835, na mesma Matriz do Santíssimo Sacramento de Itaparica, José batizou a escrava africana Carolina, pertencente ao senhor João Gonçalves. ${ }^{14}$ Quatro dias depois daquele fatídico ano para a classe senhorial da Bahia, José apadrinhou, ao lado da madrinha africana Joaquina, a sua conterrânea Maria, pertencente ao conhecido Francisco Pereira da Costa. ${ }^{15}$ Pronto: José ainda era escravo, mas, hierarquicamente superior aos recém-chegados, já gozava de um prestígio distinto entre os seus conterrâneos e parecia ser sempre requisitado pelo seu senhor, cuja escravaria era notável para os padróes locais.

Os limites impostos pelas fontes paroquiais impedem, na maior parte das vezes, a descrição do cenário quase apoteótico da celebração religiosa onde escravos e senhores comungavam, aparentemente, a mesma religião e recebiam as bênçãos de um padre que derramava óleo sagrado sobre as cabeças dos novos fiéis na pia batismal. Infelizmente, nos registros feitos pelos clérigos não há descrição minuciosa a respeito de como esses africanos foram introduzidos no mundo católico, ainda que eles pouco soubessem dos seus dogmas e preceitos e raramente entendessem superficialmente a língua dos brancos.

É lamentável também que esse tipo de fonte não revele detalhes das características físicas das pessoas que viveram à época, como eventualmente fazem os processos-crime, eclipsando detalhes tão importantes do quotidiano da escravidão e dos escravos. Se se fizesse o contrário, teríamos amplas condições de descrever as feiçôes, a linguagem corporal, os olhares assustados e as manifestaçóes de alegria, além de sorrisos incandescentes como às vezes aparecem em fotografias de época e são narrados em outras fontes do período. Durante toda a história da escravidão, pela própria natureza do horrendo processo, tornou-se corriqueiro o silêncio e a invisibilidade parcial dos cativos por meio dos registros produzidos pelas próprias classes dominantes. Ao historiador, cabe a argúcia de captar, nos pormenores dessas fontes, sinais de vida daqueles que procuramos. Os batismos não são completos, mas podem ser o começo e novelo para desvendar trajetórias.

Assim, enquanto José seguia batizando seus conterrâneos, uma nova leva de escravizados, procedentes da África, traria para Itaparica outro sujeito protagonista dessa história.

\footnotetext{
${ }^{13}$ Disponível em: <https://familysearch.org/pal:/MM9.3.1/TH-1-18354-12815-23?cc=2177272\&wc=M97YPL5:24182851>. Livro de batismos da Freguesia do Santíssimo Sacramento de Itaparica, Livro B, 1815-1840, n. 1, fls. 70-71. Acesso em: 20 jan. 2014.

${ }^{14}$ Ibid, p.103.

${ }^{15}$ Ibid, p. 104.
} 
E, como sempre ocorria com os africanos mareados da longa travessia e recém-chegados ao Brasil, certo dia o padre local registrou no livro de assentos o seguinte:

Ao vinte seis do mês de dezembro de 1834, nesta Matriz do Sacramento de Itaparica, batizei solenemente a Marcos, africano, escravo de Theodoro Ferreira Pimentel, foram padrinhos Gregório, escravo de Antônio dos Santos, e Felicidade, escrava de João Antunes Guimarães, todos desta Freguesia. ${ }^{16}$

Diferentemente de José, aquele que mais tarde viria se chamar Marcos Theodoro Pimentel, o Marcos velho, ingressou no Brasil numa conjuntura econômica, política, social e do tráfico completamente inversa. Ele foi mais um daqueles considerados africanos livres por ter entrado em terras brasileiras após a aprovação da lei que proibia a importação de africanos. De modo inusitado, não consta em nenhuma documentação algo que pudesse aventar a reivindicação de Marcos ao seu direito à liberdade. Nem mesmo em seu testamento ele faria alusão à sua chegada ao Brasil após 1831 e sobre a forma como conseguira a sua liberdade.

No decorrer dos treze anos da sua chegada até a morte do seu senhor, Marcos não lograra o mesmo prestígio que o seu futuro compadre. Fosse por falta de interesse, de oportunidade ou por timidez, ele se reservou ao anonimato, dedicando-se, provavelmente, aos afazeres que lhes eram impostos, sem batizar ninguém; apenas foi batizado. Porém, em mais uma dessas raras coincidências da História, os senhores de Marcos e José faleceriam no mesmo ano, trazendo novas notícias deles. Saber um pouco quem eram e o que faziam aqueles homens ajuda a compreender o mundo do cativeiro ao qual estavam submetidos os dois africanos durante aqueles anos. E comecemos por José.

Durante as últimas décadas de euforia do mercado escravagista, Isidoro Martins Braga comprou vários cativos, alguns deles na praça da cidade do Salvador, e os transportou para a Ilha. Como dito anteriormente, ao todo, às vésperas do seu passamento, eram 31 escravos em seu domínio, alguns deles com especialidade no ofício de "marítimo", ou "do mar", somados aos dedicados às tarefas de roça. Outros lidavam com a fabricaçáo da cachaça no alambique existente na fazenda, à navegação, aos serviços de rua e às tarefas domésticas.

Conforme desnudamos seu inventário, percebemos que Isidoro fazia questão de esbanjar fortuna e, talvez prevendo sua morte, já vinha doando cativos para seus entes queridos. Assim, quando os avaliadores resolveram aquilatar sua escravaria, outros cativos foram aparecendo na medida em que os avaliadores intimavam os herdeiros a apresentarem aqueles já aquinhoados.

Sob o domínio do seu primeiro senhor, José penou no duro trabalho de roça. Naqueles idos tempos, ele ainda não havia mergulhado no mundo marítimo dos caçadores de baleia,

\footnotetext{
${ }^{16}$ LIVRO de Assentos de Batismos da Paróquia do Santíssimo Sacramento de Itaparica. Disponível em: <https://familysearch.org/pal:/MM9.3.1/TH-1-18354-12488-12?cc=1719212\&wc=M93K-7PN:n1046202725>. Acesso em: 31 maio 2013. p. 91.
} 
dos pescadores de rede de arrasto, dos saveiristas transportadores de mercadorias para os principais centros urbanos do Recôncavo e para a capital, como faziam os seus parceiros de cativeiro. Contudo, é bem provável que tenha sido na propriedade desse primeiro senhor o local onde estabelecera os contatos preliminares com a "gente do mar" e aprendido muita coisa acerca da arte da pesca e da navegação. Nos momentos de desocupação, ele observava atentamente a labuta de seus parceiros no mar, manuseando os instrumentos sobre as embarcações.

$\mathrm{Na}$ fazenda de Isidoro, as condiçôes materiais de existência também propiciavam o nascimento de "crias", e famílias se formaram, talvez uma intencional estratégia senhorial para garantir a reprodução da força de trabalho cativo já num período decisivo da história da escravidão no Brasil. Embora as relaçôes afetivas não fossem uma prerrogativa dos senhores e os cativos não tivessem por costume solicitar autorização para estabelecer relaçóes conjugais, situaçôes propícias tenderam a ajudar na consolidação da família, a exemplo do equilíbrio entre os sexos no âmbito da propriedade e ingresso de mulheres em idade compatíveis à procriação. Ainda que essa não fosse uma característica da propriedade de Isidoro, posto a maioria dos cativos ser do sexo masculino, a avaliação de três crianças no rol do inventário sugere a existência de relaçôes de parentesco e afetividade entre os cativos que ali viviam.

Isidoro Martins Braga foi um homem muito vaidoso, apreciador do luxo e da ostentação, além de fazer questão de bancar presunção e extravagância, como ficaria evidenciado em seu inventário. Dentre os seus diversos pertences pessoais carregava sempre um relógio de bolso, "óculos de ver ao longe", um binóculo, por onde, provavelmente, ele assistia a entrada e a saída de navios negreiros, na Baía de Todos os Santos, trazendo novos africanos, além de ver as suas embarcaçóes navegarem rumo à cidade do Salvador para descarregar mercadorias produzidas em solo itaparicano.

Do pujante alambique, instalado em sua fazenda, localizada nas imediações da vila de Itaparica, composto por itens de valor significativo, assim observado pelos avaliadores, Isidoro mantinha a sua principal fonte de renda. Cisternas, tanques, um telheiro para a fabricaçáo da cal, outro que servia de depósito para esse produto, quase tudo se encontrava em estado pouco degradado quando ele veio a falecer. No centro da propriedade e de frente para o mar, destacava-se a pomposa casa de campo, onde o casal residia, avaliada na ordem de um conto e quinhentos mil réis.

Sempre ao cair da tarde, os escravos e os trabalhadores livres, antes de se recolherem aos seus aposentos, tratavam de ancorar no cais da fazenda a lancha bieira, denominada jararaca, o saveiro de 42 palmos de quilha e duas canoas; embarcaçóes de cabotagem, tipicamente usadas no transporte de mercadorias e na pesca litorânea, respectivamente. Redes de "espera", de "arrastar camarão" e "arraeira", juntamente com os apetrechos das embarcaçóes, faziam parte dos equipamentos quotidianamente utilizados pelos escravos marisqueiros, pescadores e embarcadiços em suas jornadas de trabalho no mar e nos rios. 
Durante as décadas precedentes ao seu falecimento, Isidoro pôde, assim como outros senhores de Itaparica, ostentar o fausto e a riqueza, comprando, regularmente, escravos na praça da cidade do Salvador para recompor e ampliar a sua escravaria. Sistemático, ele registrou, detalhadamente, toda a movimentação financeira em um diário, espécie de livro de contas, onde declarou as receitas e as despesas contabilizadas nos seus últimos anos de vida. Em vinte de outubro de 1840, por sinal, ele já não mais caminhava pelas ruas irregulares e esburacadas da vila de Itaparica, pois adquirira uma cadeira de arruar, a qual era conduzida sobre os ombros de seus cativos e, na época, lhe custara $8 \$ 680$ réis.

Em Salvador, ele comprava, frequentemente, nos armazéns da Cidade Baixa, muita farinha, carne de gado, carne-seca e de tartaruga, ingredientes que compunham a dieta básica para sua família e a ração para os seus escravos, assim declarou. Nesse mesmo mercado, adquiria constantemente uma variedade de tecidos de brim grosso, linhas de barca e fio de algodão para costurar roupas e dar de vestir aos seus cativos, ganhos materiais conquistados com muita luta pelos oprimidos. Salientava, na ocasiāo em que enviava recomendaçóes por escrito aos seus credores, para que tais mercadorias fossem entregues impreterivelmente ao escravo Idelfonso, marinheiro e embarcadiço de confiança responsável pelo seu transporte, por meio do saveiro, na rota para a Ilha de Itaparica. E não era só isso.

Em 29 de julho de 1841, Isidoro comprou o escravo Crispim e mais carne de tartaruga. Seis meses depois, em 30 de dezembro do mesmo ano, voltou à capital e arrematou um novo escravo, descrito apenas como um "moleque de nação nagô", pelo valor de quatrocentos mil réis. $\mathrm{O}$ tráfico persistia às escondidas e contando com a cumplicidade das autoridades provinciais.

$\mathrm{Na}$ medida em que os anos passavam, que os seus filhos cresciam e se casavam, Isidoro foi doando parte da sua escravaria para cada um deles. Assim, após o seu falecimento em 19 de julho de 1847, uma das primeiras atitudes dos avaliadores foi solicitar a apresentaçáo dos cativos aquinhoados por cada um dos filhos. Foi aí que José Nagô apareceu então como cativo já doado ao herdeiro e filho Severo Martins Braga, sendo avaliado em 500\$000, sadio e, segundo seu senhor, aparentando 25 anos de idade.

Severo Martins Braga era o segundo da linhagem do total de seis filhos de Isidoro. Com patente de Tenente foi ele, juntamente com a sua genitora, quem adotou todas as providências para que o sepultamento do seu pai fosse apoteótico, uma verdadeira encenação teatral, rito fúnebre de passagem da vida terrena para o mundo celestial. Sob os olhos atentos de José e de seus camaradas, todos os preparativos foram cuidadosamente arrumados para o sepultamento do velho Isidoro. Para isso, eles reservaram um lugar privilegiado no cemitério do Santíssimo Sacramento da vila de Itaparica, um padre foi imediatamente contratado e realizou várias missas durante todo o dia, além daquela tradicional de corpo presente, quando finalmente atirou-lhe água benta e encomendou a alma daquele escravocrata para o além. 
De Salvador veio, através de uma embarcação fretada, uma banda musical, filarmônica que tocou durante todo o cortejo fúnebre que desfilou pelas principais ruas da vila de Itaparica. Carpideiras também foram recrutadas e choraram no curso do cortejo. Como era de costume na época, os herdeiros tiveram o cuidado de vestir todos os escravos de preto, em sinal de luto, obrigando-os a manifestarem tristeza pelo passamento daquele que os oprimia em vida. Ao lado dos demais cativos, lá estava José Nagô, vestido de preto, com capinha de aspargos, aparentemente lamentando a morte do seu primeiro senhor e pensando em como se libertar do segundo.

Naquele mesmo ano, passado o momento de histeria quase coletiva, e assentada a poeira, os herdeiros começaram a tratar de ajustar as contas devidas pelo seu genitor. Em seu extenso documento, os avaliadores arrolaram imóveis, escravaria, bem como as suas dívidas. Enquanto os herdeiros negociavam a partilha do espólio, detalhes dos últimos anos da vida de Isidoro apareciam nas suas próprias declaraçóes. O exame microscópico do perfil da sua escravaria revelou uma amostragem da diversidade dos grupos étnicos predominantes na última fase do aprofundamento do tráfico de africanos, sobretudo na regiáo conhecida por desembarque clandestino de africanos escravizados.

Vendo-os mais detalhadamente percebemos, além de sua diversidade, o que os camaradas de José faziam na propriedade de Isidoro. Luís era um manjola do serviço do mar e da roça. Cosme era nagô, dos mesmos serviços; Justino, um cabinda de 30 anos, pouco mais ou menos, também fazia o mesmo que seus companheiros, além de iniciar a especialidade de tanoeiro. Além deles, ainda havia o nagô João, Antonio congo, este último era cozinheiro; Turíbio cabinda, ofício do mar; Pedro nagô, da roça; Manoel crioulo, da roça e já velho; a doméstica Joana manjola; a doméstica Rita cabinda; o moleque de sete anos Damião, crioulo; Jacinta, filha da escrava Rita e Carlota, crioula, filha da escrava Benedita.

Entre 1847 e 1855, toda a herança deixada por Isidoro ruiu como um castelo de cartas a ponto de a viúva clamar para que pelo menos a justiça permitisse a manutenção de uma escrava doméstica para assim cuidar dos afazeres do lar e obter alguma renda com os seus serviços de rua. O resto se foi, tudo levado à hasta pública e arrematado por senhores locais. Enquanto o inventário se desenrolava até o ano de 1861 e os herdeiros pagavam dívidas, dentre elas o custo de brim grosso e fio de algodão para fazer roupas para os cativos ainda na época de Isidoro, determinados filhos iam falecendo e alguns escravos se emancipavam. ${ }^{17}$

Até os dias de hoje, não se sabe como José alcançou a liberdade nessa conjuntura. Talvez algum registro de notas, contidos num amontoado de livros armazenados no Fórum de Bom Despacho da Ilha de Itaparica, possa revelar tal mistério. Nos anos posteriores à morte do seu primeiro senhor, teria José passado a residir à Rua dos Patos, na vila de Itaparica, endereço de Severo Martins Braga, seu novo dono? Ou ele teria alcançado a liberdade no momento em que os bens de Isidoro foram avaliados e os inventariantes, precisando de dinheiro para

\footnotetext{
${ }^{17}$ APB - Arquivo Público do Estado da Bahia. Seção Colonial/Provincial. Inventário de Isidoro Martins Braga. Doc: 4/1807/2278/15/99. Itaparica, 1847.
} 
custear gastos com o sepultamento e com o inventário, alforriaram alguns deles? A resposta a essa pergunta deve estar na sua carta de liberdade, até o momento náo encontrada. Mas, a julgar pela declaração da inventariante e viúva do casal de que vendera o escravo africano Tapa Francisco para bancar despesas com funeral, e da omissão de Severo Martins Braga em ter citado a venda de algum dos seus cativos quando procedeu a inventário do seu genitor, é provável que José tenha ficado mesmo ao seu lado até 1851, quando este veio a falecer. ${ }^{18}$ Isso converge com as declaraçóes que José faria mais tarde, em seu testamento, ao declarar ter sido escravo de Severo Martins Braga. Certo é que, por volta da década de 1850, ele já havia alcançado, de alguma forma, a sua liberdade plena sem dever mais nada a ninguém.

Mas, enquanto a emancipação de José permanece parcialmente ofuscada para nós, dado a ausência da principal fonte comprobatória, as circunstâncias extraordinárias da trajetória de vida de Marcos, contidas em sua carta de alforria, proporcionam importantes vestígios de sua vida pregressa à condição de liberto. Marcos foi escravizado pela família Pimentel, também detentora de posses e considerada uma das mais importantes escravocratas ilheenses da época, embora não fosse dedicada à baleação e o seu patrimônio líquido não fosse tão elevado. ${ }^{19}$

Considerando a época de seu ingresso como escravo na Ilha de Itaparica em dezembro de 1834, ele viveu no cativeiro por exatos 15 anos, ao passo que José teria vivido por longos 35 anos, o que reforça a tese de que ele chegou ao Brasil ainda criança. Aquele foi o tempo suficiente para Marcos aprender a profissão de barbeiro, trabalhar diariamente na vila de Itaparica e em outras localidades, entregar parte dos ganhos ao seu senhor e acumular uma quantia nada desprezível para comprar sua liberdade.

Em 5 de maio de 1849, portanto, dois anos após o falecimento do seu senhor, a viúva do mesmo, Rita Freire de Orleans Pimentel, recebeu das mãos de Marcos a razoável quantia de $900 \$ 00$ réis e registrou a sua carta de liberdade. Alguns anos antes da proeza de seu futuro compadre e amigo, Marcos finalmente passou a viver em liberdade e, assim como José, costurou uma nova existência. Vejamos como isso aconteceu.

\section{Marcos e José: livres e empreendedores}

Por volta da década de 1850, José e Marcos, já libertos, continuavam residindo na vila de Itaparica, como na época em que moravam ao lado dos seus senhores, e ninguém

\footnotetext{
${ }^{18}$ APB - Seção Colonial/Provincial. Inventário do Tenente Severo Martins Braga. Doc. 03/990/1459/13. Itaparica, 1851.

${ }^{19}$ De acordo com o inventário de Theodoro José Pimentel, sua viúva pagou o selo de herança no valor de 2:253\$910. Em 1887, sua filha, Sophia Freira de Orleans Pimentel, era considerada uma das maiores proprietárias de escravos da Ilha de Itaparica. Ver: APB - Seção Colonial/Provincial. Testamento de Theodoro José Pimentel. Itaparica, 1847. Doc: 04/1807/2278/04. CASTELLUCCI JUNIOR, Wellington. Pescadores e roceiros: Escravos e forros em Itaparica na segunda metade do século XIX. (1860-1888). São Paulo: Annablume, 2008. p. 146.
} 
sabe, ao certo, se eles já se conheciam. Esse foi um período que se revelou decisivo para a história da indústria baleeira no Brasil, pois foi um tempo em que as antigas e pujantes armações de caça e desmancho dos cetáceos entraram em declínio, dentre outros motivos, por conta do fim do tráfico de africanos escravizados e a diminuição dos animais na Baía de Todos os Santos.

Desde os tempos remotos da implantação das armações de caça e beneficiamento do óleo da baleia em Itaparica, sempre houve uma concentração de mulheres ganhadeiras, de escravos e homens livres dedicados à pescaria e à baleação nas imediaçôes e nos distritos da povoação que, mais tarde, seria a vila da Ilha. Ali, africanos costumavam se comunicar na língua nagô e a ensinavam aos nascidos no Brasil enquanto compartilhavam a rotina laboriosa de atracar embarcaçóes, tratavam o pescado e desmanchavam baleias nas imediaçóes urbanas. ${ }^{20}$ Alguns deles moraram em ruas vizinhas a de seus antigos senhores e conviveram pelo resto de suas vidas cruzando alamedas com os descendentes daqueles que um dia sugaram a sua força de trabalho e, provavelmente, os cumprimentavam.

Mas, foi no curso da segunda metade do século XIX que a presença de africanos e crioulos libertos pescadores, arpoadores e caçadores de baleia autônomos tornou-se algo relativamente comum naquelas paragens. A própria redução do tráfico de cativos contribuíra para atrair mão de obra assalariada para aquelas imediaçóes. Com efeito, para lá confluíam todos que queriam se dedicar àquela atividade promissora no recomeço da vida em liberdade. Ao chegarem ali, eles se embaralhavam com os alforriados envolvidos naquele negócio pouco rentável, já residentes naquele conglomerado de casas singelas, situadas em ruas como a dos Patos, da Glória, da Cordoaria, do Canal, no Largo da Quitanda, no Beco do Limoeiro ou em distritos como a Ilhota, o "duro" e Barra do Gil.

Ali, alguns viveram, modicamente, dos recursos retirados da pescaria miúda ou da venda do pescado em tabuleiros, sustentando a si e, às vezes, a família, quando as tinham. Sabemos da condição de vida de alguns deles por meio dos registros de seus inventários que sobreviveram para a posteridade. $\mathrm{O}$ arpoador liberto Manoel Estevão, um homem solteiro e morador no Distrito do Jaburu, terceiro distrito de Itaparica, quando faleceu em 1855, tinha tão somente uma canoa de vinhático, velha e rachada, com os pertences de pescaria, a qual foi unicamente avaliada em quarenta mil réis, e nada mais. ${ }^{21}$ A ganhadeira africana Ana Calabar morava, até 1862, no Beco do Limoeiro, e, quando partiu para a eternidade, deixou uma casinha de adobe bastante arruinada, umas saias, pedaços de panos da costa e poucos objetos domésticos sem valor. ${ }^{22}$

\footnotetext{
${ }^{20}$ APB, seção judiciária, 18/615/05. Processos-crime contra João Ricardo Bruno. Depoimento do crioulo Adão José dos Santos. Itaparica, 1884.

${ }^{21}$ APB - Arquivo público do Estado da Bahia. Seção Colonial/Provincial. Justiça. Inventário de Manoel Estevão. Itaparica, 1855-56. Doc: 08/3402/09.

22 APB - Seção Colonial/Provincial. Inventário da africana Ana Calabar. Itaparica, 1862. Doc: 03/1024/1493/15.
} 
O caminho para uma possível ascensão social e econômica estava mesmo na dedicação às atividades da baleação, mas esses anos ainda eram bastante difíceis. Quando um liberto se envolvia com esse ramo de atividade, geralmente começava a construir uma vida menos sofrível e extenuante. Contudo, esse era um investimento de médio e longo prazo, sendo a aquisição dos instrumentos de trabalho e embarcaçóes para a perseguição do animal uma demanda assaz onerosa, só passível de recuperação com o passar dos anos e com boas temporadas de aproximação das baleias na Baía de Todos os Santos. Se contassem com um mercado consumidor local e regional favorável, além da sorte de arpoar alguns cetáceos nas temporadas de caça, dentro de alguns anos as coisas poderiam melhorar.

Na década de 1850, porém, os libertos ainda não logravam grandes vantagens no trato da baleação porque contavam com a concorrência de algumas armaçóes funcionando precariamente, localizadas nos distritos do Manguinhos, Porto dos Santos e Barra do Gil. Desse modo, o arpoador liberto iniciante começava os seus negócios modestamente e em desvantagem. Ao falecer em novembro de 1855, o africano Francisco de Campos tinha, apenas, alguns instrumentos para o seu trabalho de arpoar baleias. Na oportunidade, os avaliadores intimaram a "preta africana Maria”, sua companheira que residia com ele numa casa localizada na Rua dos Patos — onde muitos crioulos e africanos libertos também moravam - a levantar os seus pertences. Registraram que ele possuía: duas tinas do serviço de baleias vazias, duas cartolas do mesmo serviço, outra cartola do mesmo serviço, já velha, vinte e quatro canadas de azeite, três alavancas, três facóes, quatro facas e uma caixa com roupas usadas no dito trabalho.

Além dos parcos bens materiais, ainda registraram "uma pequena plantação de quiabos, aipim, mandioca e mais alguns arbustos" cultivados em um quintal pertencente ao vizinho. A soma dos seus bens totalizara $64 \$ 200$ réis, sendo a quantidade de azeite e a plantação os itens mais valorizados. Deles é que foi retirada a quantia de vinte mil réis para pagamento dos direitos provinciais a José Ferrais de Oliveira, arrematante de imposto que recaía terrivelmente como licença sobre os africanos libertos que mercadejavam pelo Brasil na época. ${ }^{23}$

Não há como saber se, nesse tempo, José e Marcos se conheciam e já haviam ingressado no mundo da baleação, mas duas coisas importantes ficaram registradas na vida de um deles anos antes. Após quase quatro primaveras da compra da sua própria liberdade, Marcos voltou à carga e, em 28 de fevereiro de 1853, comprou a liberdade do seu primeiro filho, junto a José Estevão Cardoso, havido com a escrava africana Maria Cardoso, pela quantia de cem mil réis. ${ }^{24}$ Ele tinha apenas dois meses e meio de idade e seria batizado também pelo nome de Marcos, e mais tarde tornar-se-ia conhecidíssimo pela alcunha de Marcos, o Jovem. ${ }^{25}$

\footnotetext{
${ }^{23}$ APB - Arquivo Público do Estado da Bahia, Seção Colonial/Provincial. Inventários dos bens do africano Liberto Francisco de Campos. Itaparica, 1855. Doc: 08/3464/21.

${ }^{24}$ APB - Seção Judiciária. Polícia. Maço 6347. Doc:185328/02. Carta de liberdade de Marcos Cardoso Pimentel. Itaparica, 1853. Ver também Arquivo da Cúria Metropolita de Salvador/Mórmons, filme 128-4581, item 5. Batizado/Itaparica, 1840-62, f. 94.

${ }^{25}$ Pedido de passaporte do crioulo liberto Marcos, 14 de maio de 1881, APB, Polícia. Escravos, 1881-1885,
} 
Embora o tornasse liberto, Marcos não reconheceria formalmente a paternidade do seu primeiro filho naquelas idas décadas, e a sua relação com a escrava Maria Cardoso se exauriu por ali mesmo. Seu próprio filho declararia mais tarde que eles nunca se casaram.

O resgate do seu primogênito do cativeiro revelou, contudo, o quanto as relaçóes de parentesco eram importantes para os libertos, e que eles não esqueciam seus entes queridos no confinamento sob a suspeita de legitimidade paternal. Da relação de uma escrava com um liberto nasceu aquele que atravessaria o século XIX e estaria bem vivo na centúria seguinte para contar a experiência de ter vivido ao lado do seu pai e de ter conhecido o seu amigo, compadre e sócio quando todos negociavam as coisas de baleia na segunda metade do século XIX.

Àquela altura, o nagô Marcos já havia incorporado ao seu nome de batismo o sobrenome do antigo senhor e passara a se chamar Marcos Theodoro Pimentel, mais tarde Marcos, $o$ Velho. Coisa semelhante fez o seu futuro sócio José, o qual passou a chamar-se José Severo Martins Braga naqueles idos anos. Mas ele, diferentemente de Marcos, nos deixou poucas pistas nessa época, uma vez não ter constituído matrimônio e nem ter tido filhos. Se não estavam envolvidos no trato com a baleação em meados dos anos 1850, ao menos de alguma forma esses dois africanos nagôs obtiveram ganhos significativos e começavam a despontar no cenário local como homens de respeito.

Alguns anos mais tarde, já no início da década de 1860, Marcos Theodoro consagraria uma nova relação matrimonial não formalizada, desta feita com a africana Raquel, com quem teria mais dois filhos. Em 1862, nasceu José Theodoro Pimentel e, em 1864, nascia Flora da Trindade Pimentel. Seriam eles e Raquel, ao lado de Marcos Cardoso Pimentel, os herdeiros universais do nagô Marcos, como ele registrou detalhadamente em seu testamento. Treze anos haviam se passado e, considerando o registro na sua carta de liberdade, Marcos era possivelmente um homem de meia-idade, com seus aproximados quarenta e poucos anos, embora seja tão difícil mensurar a idade dos africanos que para cá vieram escravizados.

Agora, após quase duas décadas de liberdade, ele e seu futuro sócio iniciavam um virtuoso ciclo de vida social e econômica que os levaria a despontar como libertos bem-sucedidos e bem conhecidos em toda a Ilha de Itaparica. Se os anos 1850 marcaram a transição e a redenção de ambos, a década seguinte foi o momento de afirmação dos dois enquanto sujeitos independentes e emergentes. A década de 1870, por sua vez, marcaria a fase de consolidação de suas vidas, pois é a partir dessa época que as fontes começam a falar mais detalhadamente das suas atividades como baleeiros, empreendedores e conhecidos. Seus ciclos emergentes coincidem com todo o processo de decadência e falência das armaçóes de desmancho de baleia e a apropriação por parte dos libertos desse ramo de atividade, que se tornaria de suma importância para a sobrevivência da gente forra, dedicada desde a caça até a comercialização de seus derivados na Ilha, no Recôncavo e na capital da Bahia. 
À época, Itaparica contava então com uma população de aproximadamente 10.120 pessoas. Dessas, cerca de $12 \%$ eram escravos africanos e crioulos, suplantando em aproximadamente $30 \%$ o contingente populacional existente em 1848 , período imediatamente posterior à chegada de Marcos e José na Ilha. ${ }^{26}$ Nos anos 1870 , cerca de 4.630 pessoas residiam na vila e nas suas imediaçôes; dentre elas, os nagôs Marcos e José. ${ }^{27}$ Nesse tempo, embora misturados a tantos transeuntes e moradores do lugar, provavelmente eles já mantinham algum tipo de relação de amizade ou de negócios, pois residiam bem próximos.

Seus feitos já eram então conhecidos e não é sem razão que os seus nomes aparecem com certa frequência na documentação cartorária e judicial, usados como pontos de referência para a localização exata de domicílios da vila. Em 1875, Marcos Theodoro Pimentel residia num beco que fazia esquina com a Rua da Glória, e José Severo Martins Braga habitava uma casa à Rua dos Patos. O reconhecimento social desfrutado por ambos era tão expressivo que suas moradas foram citadas como pontos de localização pelo avaliador dos bens de Emílio Borges Pimentel na vila de Itaparica da seguinte forma:

(...) uma casa térrea com três janelas de frente, e parte cita à Rua da Glória com trinta e nove palmos de frente e oitenta e um de fundos (...) dividindo pelo sul com casas e beco do africano Marcos Pimentel (...)

\section{E mais:}

(...) uma outra casa a Rua dos Patos de porta e janela, (...) dividindo pelo norte com casas de Sátiro José da Costa, e pelo sul com casas do africano José Severo Martins Braga (...2)

Ora, Emílio Borges Pimentel tinha parentesco com o esposo de dona Rita Freire de Orleans Pimentel, aquela senhora de quem Marcos havia comprado a sua liberdade anos antes, após o passamento do seu senhor Theodoro José Pimentel. Além de vizinho de seu parente, Marcos também residia bem próximo, quase vizinho da ex-senhora, pois desde pelo menos 1863 dona Rita residia à Rua Direita da Matriz, cujo cruzamento era justamente o beco bem conhecido como do africano Marcos Teodoro Pimentel. ${ }^{29}$

A essa altura, Marcos Pimentel não só morava na travessa da Rua da Glória, como já era proprietário de outras casas de morada espalhadas pela vila e também já tinha a propriedade para o trato das baleias no Manguinho. Em 1871, por sinal, ele vendera ao seu filho duas casas das quais era proprietário na vila de Itaparica, uma situada à Rua da Glória e outra à

\footnotetext{
${ }^{26} \mathrm{APB}$ - Seção judiciária. Quadro numérico da população livre de 14 municípios d'esta Província da Bahia. Secretaria de Polícia da Bahia, 16 de fevereiro de 1848.

${ }^{27}$ APB - Mapa Estatístico da Província da Bahia. 1876.

${ }^{28}$ APB - Seção Judiciária. Inventário de Emílio Borges Pimentel. Itaparica, 1875. Doc: 05/2064/2535/11.

${ }^{29} \mathrm{APB}$ - Seção Judiciária. Inventário dos bens de João Macário das Chagas. Itaparica, 1863. Doc: 03/1040/1509/16.
} 
Rua do Limoeiro, ambas térreas e precisando de consertos. Embora tivesse vendido as casas ao filho, ainda não fora aquele o momento que reconheceria oficialmente Marcos Cardoso como seu filho legítimo, mas não há dúvidas de que Marcos construiu uma sólida amizade com o seu primogênito desde o seu nascimento. À época da venda da casa, Marcos Cardoso tinha tão somente 19 anos, e eles já eram sócios nos negócios da baleação, tendo inclusive uma baleeira ativa em sociedade.

E, enquanto Marcos Theodoro Pimentel cuidava dos seus filhos, comprando casas e ajustando a vida deles e da já liberta africana Raquel, o seu amigo e compadre José Severo Martins Braga tratava, com argúcia, dos seus negócios. Se, na época do cativeiro, Marcos buscou o anonimato enquanto José se destacava como padrinho de muitos, no mundo dos libertos, José buscou vida solitária, ao passo que Marcos foi o grande catalisador e mediador entre os dois mundos. Para o primeiro, a liberdade demarcou a época de agregação e reconhecimento social e familiar. Ao segundo, foi momento de expansão dos negócios, de ascensão econômica e de isolamento. Um foi pragmático, o outro carismático.

Ao seu modo, ambos ajudaram, e muito, aos seus conterrâneos e camaradas de cativeiro. A liberdade foi uma experiência bem diversificada para cada um e eles a tomaram de modo particular, a despeito de se aproximarem cada vez mais. Isso demonstra também que após a vida em cativeiro nem sempre os libertos buscaram constituir famílias e laços de sociabilidades por meio de convívio doméstico. Muitos deles também optaram por viver na solidão ou sozinhos, embora sempre conectados ao mundo dos seus próximos e bem atentos a tudo o que acontecia.

\section{A África, a casa e o sepulcro}

Num dia dos primeiros anos da década de 1880, os nagôs Marcos Theodoro Pimentel e José Severo Martins Braga estavam sentados num banquinho feito com ossada de baleia, em frente à praia do Manguinho, observando atentamente o movimento das embarcaçóes que chegavam do mar noticiando a aproximação dos cetáceos nas águas da Baía de Todos os Santos. Era época da safra que começara no mês de maio e se estenderia até outubro do ano corrente, o sol estava firme e a água cristalina. No passado, mais de duzentas baleias eram mortas todos os anos e as cinco armaçóes de Itaparica funcionavam a todo vapor, sob a força do braço cativo, baforando fumaça pelas chaminés e exalando um forte odor por toda a vila e povoados circunvizinhos. ${ }^{30}$

Agora, com a escravidão em sua reta final, os amigos/sócios contabilizavam os seus ganhos ao tempo em que meditavam acerca do que fizeram ao longo de suas vidas em liber-

\footnotetext{
${ }^{30}$ Em seu estudo pioneiro, Miriam Ellis apontou algumas dessas armaçôes em pleno funcionamento e o número de cetáceos arpoados nos períodos de "safra". Por vezes, esses números chegaram a duzentos animais. Ver: ELLIS, Miriam. A baleia no Brasil Colonial. São Paulo: Edusp, 1968. p. 43.
} 
dade. Depois de anos, capturados e retirados da sua terra natal e escravizados num mundo inóspito, eles triunfaram e juntos construíram uma fortuna considerável para os padróes dos libertos da Ilha. Bem diferente daqueles arpoadores que viveram nos anos 1850, eles não levaram uma vida material e espiritual modesta e de privaçóes em seus últimos anos de existência. Com cicatrizes pelo corpo e as mãos calejadas de puxar cordas, tratar o costado das embarcaçóes e arpoar baleias, eles, agora, com idade avançada, descansavam sobriamente à frente do oceano que lhes trouxe muitas glórias e também infortúnios.

Finalmente, eles haviam chegado ao topo de uma rede de negócios que se estendia do dono das baleeiras e casas de desmancho até as pequenas ganhadeiras que viviam mercadejando a carne moqueada e as vísceras de baleia pelas ruas da vila de Itaparica, em Salvador e em várias cidades do Recôncavo Baiano. Além desses sujeitos, a rede contava com fabricantes e fornecedores de cordas, carpinteiros, marceneiros, calafates e outros indivíduos que de alguma maneira estavam vinculados e dependentes dos negócios da baleaçáo.

De fato, todo o ciclo de vida dessa gente estava condicionado à chegada das baleias nas águas da Baía de Todos os Santos. A proximidade da estação de caça dos cetáceos na Baía seduzia africanos libertos que deixavam suas ocupaçóes onde quer que estivessem na parte continental do Recôncavo, e migravam para trabalhar provisoriamente na caçada e nas armaçôes. Quituteiras da capital atravessavam, de saveiros, o grande golfo para comprar carne moqueada e óleo para abastecer a capital, e escravos de ganhos também participavam de um frenético comércio que, por muitos anos, a câmara Municipal de Itaparica tentou disciplinar. ${ }^{31}$ Pessoas físicas financiavam a expedição emprestando dinheiro aos baleeiros, donos de mercearias antecipavam suprimentos para a tripulação e, posteriormente, recebiam o capital e os juros com o lucro da matança de baleias e da gordura animal processada.

Se, na década de 1850, ainda havia algumas armaçóes tradicionais funcionando precariamente e baseadas no trabalho escravo, nos anos vindouros os libertos tomaram conta desse negócio e passaram a monopolizar a produçáo do azeite, da carne e demais derivados do cetáceo, que à época aparecia em menor quantidade nas águas da Baía de Todos os Santos. O universo da baleação havia atravessado uma grande reviravolta e jamais seria o mesmo de tempos anteriores, do glamour da época das grandes armaçóes. Ele agora pertencia aos libertos, em particular a alguns africanos.

Marcos e José foram, sem sombra de dúvida, os mais bem-sucedidos dentre todos eles, e agora, já idosos, gozavam de um prestígio incrível junto aos seus conterrâneos e à população em geral. E isso era fruto de uma dura luta laboral e de uma fraternal amizade que começara, provavelmente, há mais de quinze anos.

\footnotetext{
${ }^{31}$ Sobre o comércio praticado pelas ganhadeiras e as tentativas de disciplinamento do comércio dos derivados da baleia, ver CASTELLUCCI Junior, Wellington. Mercando pelo Brasil oitocentista: ganhadeiras, arpoadores e traficantes de derivados de baleias no Recôncavo Baiano (1850-1900). In: LEAL, Maria das Graças de Andrade; MOREIRA, Raimundo Nonato Pereira; CASTELLUCCI JUNIOR, Wellington (Orgs.). Capitulos de História da Bahia: Novos enfoques, novas abordagens. São Paulo: Annablume, 2009. p. 77-100.
} 
Apenas para efeito de recordação, por volta dos anos 1870, Marcos Theodoro Pimentel já era um comerciante bem estabelecido na vila de Itaparica. Além do domicílio situado à Rua da Glória, ele possuía mais três casas, sendo uma delas comercial, localizada no Largo da Quitanda, área privilegiada da vila. Em Manguinho, estava fixada uma modesta casa que servia para o desmancho e processamento da gordura animal que resultava no valioso e apreciado óleo de baleia. Ali estavam todos os equipamentos necessários para o funcionamento da fábrica. Havia um saveiro de trinta palmos, uma lancha baleeira, dois burros de carga e mais objetos contidos na fábrica, como os tachos de cobre, arpóes, facóes e grelha. ${ }^{32}$

Tal como ele, seu sócio também residia na vila há muitos anos. Estabelecido confortavelmente numa morada à Rua dos Patos, José Severo Martins Braga administrava seu patrimônio que, na época, girava em torno de seis casas de morada na vila de Itaparica, mais duas em Manguinhos, e mais onze braças de terras naquele distrito. Ali mesmo estavam fundeados uma lancha baleeira, dois saveiros e um batelăo, próprio para o trabalho de baleia. Seus dois cavalos pastavam na manga de uma fazenda que ele comprou no distrito das Amoreiras, local bem próximo do Manguinhos. Suas armaçóes de baleia possuíam razoável estrutura de funcionamento, conforme declaradas pelos avaliadores:

Uma casa, no já referido lugar Manguinho feita de adobes e coberta de telhas, dividindo por um lado com casa do espólio de José Severo Martins Braga, que se está avaliando, e do outro com casa de Modesto Avelino de Jesus, avaliaram em trezentos mil réis. Outra casa, no mesmo lugar, com os mesmos cômodos da já mencionada (...) trezentos mil réis. ${ }^{33}$

E, no interior das ditas casas de desmancho, eles observaram o seguinte:

Quatorze taxas de ferro, existentes em duas casas no referido lugar do Manguinho, avaliaram em vinte mil réis cada e todos em duzentos e oitenta mil réis. Vinte tinas de madeira, avaliaram a três mil réis cada uma e todas em sessenta mil réis. ${ }^{34}$

Durante aqueles anos, Marcos e José circulavam pelas ruas da vila, eram vistos e cumprimentados pelas pessoas e se deslocavam frequentemente para o distrito do Manguinhos para fiscalizar seus funcionários e fazer funcionar suas indústrias baleeiras. A caça de baleia havia se tornado um negócio de menor escala em importância na pauta das exportaçôes brasileira, pois os Estados Unidos da América intensificaram a baleaçáo por toda a costa atlântica e pacífica dificultando, naquele momento, a sobrevivência da indústria baleeira brasileira que

\footnotetext{
${ }^{32}$ APB - Seção Colonial/Provincial. Inventário do africano Marcos Theodoro Pimentel. Itaparica, 1886. Doc: 05/2066/2537/08.

${ }^{33}$ APB - Inventário de José Severo Martins Braga.

${ }^{34}$ APB - Seção Colonial/Provincial. Inventário do africano José Severo Martins Braga. Itaparica, 1883.
} 
agonizava com o final da escravidão e a redução drástica de animais na sua costa. ${ }^{35}$ Foi nesse período que se abriu uma fenda, e esse negócio passou às mãos dos libertos que, embora matassem baleias em pequena quantidade, puderam articular um negócio miúdo e, por vezes, furtivo, porém suficientemente rentável para promover a ascensão econômica e social de alguns deles.

Ainda que a forma de perseguição e captura do animal continuasse praticamente a mesma que a de séculos anteriores, uma coisa havia mudado radicalmente. Em lugar de escravos, agora a força do trabalho que punha em movimento toda a indústria baleeira era livre e assalariada. Assim é que os sócios contratavam, por temporada, trabalhadores livres para a empreitada no mar e em terra firme. As prestaçóes de contas anexadas aos inventários daqueles dois africanos nagôs comprovam não só a relação que mantinham com trabalhadores assalariados, mas a forma como estes eram remunerados e os credores com os quais eles mantinham ativos. A esse respeito, Modesto Avelino de Jesus, único herdeiro de José Severo Martins Braga, declarou algo bem importante quando se deduziam os valores do espólio do finado nagô:

(...) Declarou que em vida do finado a baleeira de que é arpoador Agostinho Pitanga matou cinco baleias e a este e aos mais da tripulação, conforme os quesitos do mesmo, aliadas as quantias adiantadas, deve o casal $433 \$ 00$ a mesma tripulação, que como se sabe, só se paga no fim da safra. ${ }^{36}$

Se a remuneração era posterior ao fechamento do ciclo da caça, havia, porém, necessidades básicas imprescindíveis para pôr os homens em bom estado de ânimo e bem preparados para enfrentar os riscos do mar que não podiam esperar. Além da dieta alimentar, baseada em carne-seca, torresmo, farinha de mandioca, bolacha e pão, outros ingredientes entravam na lista de despesas prévias para com os trabalhadores do mar. Mantê-los com o moral elevado, alimentando hábitos e costumes bem próprios da gente costeira, eram obrigaçóes dos donos das baleeiras e das armaçóes. Um comerciante bem conhecido no distrito do Manguinhos, e também muito próximo de José Severo Martins Braga, fez um minucioso requerimento, após a sua morte, onde dizia:

\footnotetext{
${ }^{35}$ Ver a esse respeito as seguintes obras: HORNE, Gerald. O sul mais distante: Os Estados Unidos, o Brasil e o tráfico de escravos africanos. São Paulo: Companhia das Letras, 2010; CALONIUS, Erik. O último navio negreiro da América. Rio de Janeiro: Record, 2008; PHILBRICK, Nathaniel. Mar de glória: Viagem americana de descobrimento. São Paulo: Companhia das Letras, 2005; PHILBRICK, Nathaniel. A vingança da baleia: A verdadeira história do baleeiro Essex. São Paulo: Companhia das Letras, 2003; CASTELLUCCI JUNIOR, Wellington. Caçadores de baleia: Armaçōes, arpoadores, atravessadores e outros sujeitos envolvidos nos negócios do cetáceo no Brasil. Sáo Paulo: Annablume, 2009; KUGLER, Richard C. The penetration of the Pacific. In: CLARK, Joanna Gordon (Org.). Mammals in the Seas. General Papers and Large Cetaceans. Food and agriculture organization of the United Nations, Rome, 1981. v. II, p. 321-326.

${ }^{36}$ APB - Seção Colonial/Provincial. Inventário do africano José Severo Martins Braga. Itaparica, 1883. Doc: 04/1544/2013/16.
} 
Braulio Euthimio dos Santos vem pedir a V.Sa que seja atendida a conta junta que lhe ficou a dever o finado José Severo proveniente dos gêneros que o suplicante fornecia aos baleeiros d'aquele, ficando de pagar o que nunca o fez, notando V.S $\underline{a}$ que os herdeiros, e o inventariante nenhuma dúvida porão, pois estão bem cientes dessa conta, e, portanto, o suplicante confiado na justiça, e retidão de V.S ${ }^{a}$, espera ser atendido. ${ }^{37}$

Em anexo ao requerimento, ele apresentou uma extensa e interessante lista de itens retirados da sua loja de molhados pelos tripulantes da baleeira durante uma das temporadas de caça de baleia, antes do passamento do seu patrão. Dentre os vários gêneros, constavam: "muita cachaça, bolacha, maços de cigarro, várias garrafas de vinho, manteiga, charutos, óleo de rícino, tamancos, açúcar, pregos, chapéu de palha, farinha, bacalhau, consertada(?), carne, gás" e outros itens. No final da extensa lista, ele ainda registrou algo bem importante: "Todos estes gêneros tenho testemunha que viram o falecido mandar tomar quando chegavam suas baleias, tirada a conta por Braulio Euthimio dos Santos". ${ }^{38}$

José Severo desfrutava de grande prestígio no meio social. Isso lhe conferia credibilidade suficiente para que os seus baleeiros, e demais membros da tripulação, retirassem gêneros de primeira necessidade dos armazéns a crédito na época em que estavam empenhados em matar cetáceos, os quais seriam honrados com os lucros das safras da baleação. E esse prestígio não se resumia apenas à localidade do Manguinhos. No curso dos anos 1870 e até os últimos dias de vida, José Severo sempre gozou de crédito e de muita confiança junto a comerciantes e a gente comum de outros lugares, inclusive junto a comerciantes de Salvador.

Contam os mais próximos que ele não precisava estar presente na localidade para que as questóes essenciais ao funcionamento do seu empreendimento fossem resolvidas. Xisto Monteiro dos Santos, um dos seus credores na época, entrou com pedido de ressarcimento de despesas que teve com mão de obra para o conserto do saveiro de José Severo, alqueire de farinha, canada de bebida, garrafas de vinho do Porto, de vinho branco, pares de tamanco, tudo demandado pelos seus funcionários. Ele sabia que, ao final do período de safra, José costumava lhe pagar em espécie ou da maneira que ele próprio registrou em uma dedução feita da dívida existente de José para com ele:

(...) Declara o suplicante que do principal prêmio vencido até o dia de hoje importa este débito em 448\$750 réis; mas que tendo recebido do mesmo a quantia de cinquenta mil réis, em azeite que o mesmo comprara, deduzidos $50 \$ 000$ réis da referida quantia, vem a ser o débito, cujo pagamento pede $398 \$ 750$ réis. $^{39}$

\footnotetext{
${ }^{37} \mathrm{APB}$ - Seção Colonial/Provincial. Inventário de José Severo Martins Braga.

${ }^{38}$ Ibid.

${ }^{39}$ Ibid.
} 
Óleo de baleia usado como moeda corrente e relações com credores de status social e jurídico diferentes denotavam o caráter informal e a complexidade da urdidura que enredava gente que, de alguma maneira, ganhava dinheiro ou participava indiretamente desse negócio capitaneado pelos dois africanos empreendedores. Além de comerciantes e agiotas que antecipavam mantimentos e dinheiro ao africano José Severo, também constava em sua relaçáo de credores uma escrava que, por meio do seu procurador, registrou o seguinte:

Diz Lourença, crioula, escrava de Elias José de Miranda que em vida de José Severo Martins Braga emprestou a este a quantia de cento e cinquenta mil réis como se vê da letra junta e estando a concluir-se o inventário do mesmo (... $)^{40}$

Parte das dívidas contraídas por José Severo nos últimos dias de vida foi quitada, e o seu inventariante, Inocêncio da Costa e Silva, explicou em suas declaraçôes como isso fora feito: "que a conta de fs 29 está paga com o azeite que ficou no tanque ao tempo do falecimento do inventariado porque o mesmo azeite estava obrigado a esse pagamento". ${ }^{41}$

José viveu dias de glória e náo deixou de aproveitar a vida da melhor maneira que acreditava. Além de investir na evolução patrimonial, a qual chegou à modesta cifra de 4:775 $\$ 550$, sem computar as deduçóes finais, ele cuidou criteriosamente da sua gente e foi um bon vivant. Em suas listas de compras em lojas de molhados, constam compras de tecidos e outros itens de uso feminino que ele provavelmente presenteava suas amigas e funcionárias.

Ao final de sua vida, ele preocupou-se em amparar aqueles que lhe estiveram próximos e os que foi conhecendo ao longo de sua trajetória. Seu testamento é um verdadeiro inventário de solidariedade, construção de identidades e consolidação dos sentimentos de irmandade e da noção sólida de parentesco não consanguineo. Após descrição dos seus pertences, demonstrou desprendimento de bens materiais e foi cuidadosamente elencando propriedades deixadas para algumas mulheres que, de alguma maneira, estiveram ao seu lado:

(...) Deixa (a) Maria, africana liberta, que foi escrava do senhor Joaquim que cobrará foros da minha casa a Rua Direita da vila de Itaparica, para gozá-la enquanto vida tiver, e por morte da mesma Maria passará ao já dito herdeiro Modesto Avelino de Jesus. Deixo de fato e de direito a minha casa a Rua da Glória a Emília, africana liberta, a qual comprou com meu dinheiro, porém em nome dela - deixo mais a mesma Emília acima dita a minha casa a Rua dos Sete Pecados, para ela usufruir somente e por morte passará a meu já dito herdeiro Modesto Avelino de Jesus $(. . .)^{42}$

\footnotetext{
${ }^{40}$ Ibid.

${ }^{41}$ Ibid.

${ }^{42}$ APB - Seção Colonial/Provincial. Testamento de José Severo Martins Braga. 
Mas elas não foram as únicas beneficiárias de seu reconhecimento. A instituição do compadrio e do batismo, tão fortemente marcante na vida de José, sobretudo quando batizou os que chegavam da África quando ele ainda era cativo, também pesou em suas últimas disposiçôes. Além de alforriar o afilhado - cuja carta encontra-se anexada ao inventário - ele deixou algumas recomendaçóes para outros sujeitos, inclusive relativas ao seu velho compadre Marcos:

Deixo meu afilhado Pedro, escravo do Coronel Pinto do Catu, quatrocentos mil réis para sua liberdade, a qual quantia se lhe entregará livre de selo de herança, antes da prestação de contas desta. Ordeno a meu herdeiro Modesto Avelino de Jesus que não deite meu compadre Marcos Theodoro Pimentel, meu terceiro testamenteiro, para fora das terras que lhe dei para fazer sua roça.

Ordeno a Emília, africana minha herdeira que não deite para fora do quarto que ocupa o preto Antonio, e se não cumprir em minha alma sofrerá. ${ }^{43}$

Para além de todas essas disposiçóes, seu testamento também revela a concretude das relaçôes sociais que, em movimento histórico, redefinem papéis sociais dos indivíduos e os seus lugares no meio do qual estáo inseridos, a despeito do seu recinto de origem. Foi por isso que, ao final de sua vida, José já não carregava, acoplado a seu nome, o epíteto de africano. Nos últimos tempos, tanto os seus credores quanto as autoridades cartorárias o tratavam como senhor José Severo Martins Braga e não como "o africano". Finalmente, e contraditoriamente, as suas origens africanas deixaram de ser "chagas" que carregara ao longo da vida e desapareceram para sempre do imaginário social dos ilheenses e dos comerciantes da capital. Parecia que, para ter reconhecimento social, ele, assim como outros, teve de negar a sua origem extracontinental, africana. Como ele e tantos outros se relacionaram com tal dilema, jamais saberemos.

A seu pedido, seu célebre testamento foi redigido em 15 de setembro de 1883, justamente em sua residência à Rua dos Patos, quando já se encontrava acometido de uma grave moléstia. No auge da sua enfermidade, diagnosticado como problemas no fígado, José rejeitou as recomendaçóes médicas tradicionais e os medicamentos da botica. Provavelmente numa clara alusão aos conhecimentos de tradiçôes africanas e apelando para Ossain, ${ }^{44}$ afirmava que queria "curar-se com suas folhas; pelo que o doutor Portella retirou-se e não mais voltou". No dia 18 do mesmo mês e ano, José Severo Martins Braga falecia pobre e ali se encerrava a vida de um importante baleeiro itaparicano. Lamentavelmente, náo sabemos qual o local de seu sepultamento, pois o livro de registros de óbitos da Freguesia do Santíssimo Sacramento,

\footnotetext{
${ }^{43}$ Ibid.

${ }^{44}$ Ossain é o Deus das ervas e do segredo. Ver sobre isso: BARROS, José Flávio Pessoa; NAPOLEÃO, Eduardo. Ewe òrisá: uso litúrgico e terapêutico dos vegetais nas casas de candomblé jêje-nagô. 4. ed. Rio de Janeiro: Bertrand Brasil, 2009.
} 
desse período, foi extraviado. Mas, certamente, o seu sócio e compadre esteve presente naquela solenidade de adeus ao parceiro de luta.

Ao final de sua vida, Marcos Theodoro Pimentel também procurou registrar seu testamento e acertar algumas pendências existentes. Talvez a mais importante delas foi reconhecer, como legítimo, o seu filho Marcos Cardoso Pimentel, aquele que há muitos anos já era seu sócio e seria o responsável pela condução de todos os procedimentos de seu inventário.

Assim, justamente em 25 de abril de 1881, em sua casa na vila de Itaparica, cinco anos antes da sua morte, e dois antes do passamento de José Severo, ele tratou de regularizar a situação de todos aqueles que viviam no seu círculo de amizade e os quais ele amparou ao longo de sua vida como homem de negócio que foi. Não esqueceu também de mencionar como terceiro testamenteiro o seu amigo e sócio José Severo Martins Braga, pedindo a cada um que cumprisse a verba testamentária para que sua alma não sofresse.

Provavelmente, ele já havia planejado, naquele momento, um grande salto espiritual, o qual deixaria seu nome gravado para sempre na memória dos itaparicanos. Em 13 de maio de 1881, Marcos Theodoro Pimentel e seu filho Marcos Cardoso Pimentel se dirigiram à capital e solicitaram à Secretaria de Polícia da Bahia concessão de passaporte para que assim eles pudessem realizar uma longa viagem. ${ }^{45}$ Lisa Earl Castillo, em primoroso trabalho acerca das viagens de africanos para a África no tempo de afirmação da sua religiosidade no Brasil, destacou a façanha do pai e do filho ainda naquele ano:

O patriarca da família, um liberto nagô consagrado Xangô Aganju, Marcos Theodoro Pimentel, era adepto do culto iorubá aos ancestrais, no Brasil conhecido como Babá Egun. Marcos Theodoro tinha dois filhos, Marcos Cardoso Pimentel e José Theodoro Pimentel. Em maio de 1881, o jovem Marcos viajou a Lagos com seu pai, retornando em novembro do mesmo ano. É dito que na volta trouxeram um assento de babá Olukotun, ancestral legendário dos povos iorubás, cultuado até hoje nos terreiros de Babá Egun da Bahia. ${ }^{46}$

O registro de viagem à África completou o ciclo de sua vida com a proeza de regressar a sua terra natal, ao lado do seu filho, e trazer para o Brasil o culto aos ancestrais. Para além da documentação oficial existente, esse episódio ficou guardado na memória do povo de Santo da Ilha que até os dias atuais tem Marcos Theodoro Pimentel como o fundador do culto aos Egun, cuja sede localiza-se na comunidade do Tun-tun, em Amoreira. ${ }^{47}$ Foi lá que seus dois filhos, Marcos, o Jovem e José Theodoro deram continuidade, no século XX, ao

\footnotetext{
${ }^{45}$ APB - Polícia. Pedido de Passaporte do crioulo liberto Marcus, 14/05/1881. Escravos, 1881-1885, maço: 6347; Entrada de passageiros (1879-1883), v. 3. Ver também inventários de Marcos Theodoro Pimentel, 13/07/1886. Doc: 05/2066/2537/08.

${ }^{46}$ CASTILLO, Lisa Earl. Entre memória, mito e História. Viajantes transatlânticos da Casa Branca, op. cit., p. 109. ${ }^{47}$ Ver OSÓRIO, Ubaldo. A Ilha de Itaparica: história e tradição. Salvador: Fundação Cultural do Estado da Bahia, 1979. p. 321.
} 
espaço sagrado construído por seu pai. ${ }^{48}$ Mestre Didi, figura mais importante da cultura afro-baiana da vigésima centúria e cujo passamento é recente, conheceu Marcos Cardoso e, por meio dele, foi iniciado no culto aos Egun na Ilha de Itaparica. ${ }^{49}$

No epílogo de sua vida, ao regressar do continente africano ao lado do seu filho no final de 1881, Marcos Theodoro Pimentel, além de chefe espiritual, continuou envolvido no ramo da baleação. Porém, à época, o próprio Marcos Cardoso, antevendo a impossibilidade de seu pai continuar a labutar no mar por muito tempo, formalizou nova sociedade com outro empreendedor do lugar. As declaraçóes de despesas e receitas - anexadas ao inventário - dos últimos anos de vida de velho Marcos Theodoro deslindam detalhadamente um balanço das finanças dos dois, e como o seu negócio caminhava.

Assim como seu compadre, ele também conservava prestígio junto a uma rede de comerciantes locais, além de manter, sob sua órbita, pessoal ligado à arte de matar baleias, parentes e amigos. Assim, quando seu filho Marcos Cardoso organizou a prestação de contas, ele aludiu detalhes preciosos dos últimos anos da vida de baleeiro do velho Marcos:

Além dos bens avaliados de folhas 22 a 25, cuja norma faz o acervo do inventário, a baleeira de que trata a dita avaliação, pescou três peixes, sendo dois seguilhotes e um cacharréu. Mas ocorre que a baleeira quando foi posta ao mar, foi sociedade com outrem, fornecendo o inventariado a baleeira, e o sócio o socorro da mesma, de sorte que metade do produto líquido é pertencente ao inventário e, além disso, a outra metade é do sócio.

Os dois primeiros peixes foram vendidos por $400 \$ 000$ e o terceiro por $300 \$ 000$ — importaram em 700\$000. Fez-se de despesa com arpoadores, timoneiros, moço d'armas, sete baleeiros, cordas, arpóes, adjutórios e outros baleeiros e mais coisas necessárias $522 \$ 000$. Fica líquido $178 \$ 000$.

E sendo somente metade deste líquido o lucro da baleeira nos três peixes, vem a ser o dito lucro líquido que tem de ser somado ao acervo $89 \$ 000 .^{50}$

Quando, em três de julho de 1886, Marcos Theodoro Pimentel veio a falecer, seu patrimônio fora orçado em 1:749\$000 (um conto, setecentos e quarenta e nove mil réis) que, partilhado, legou para cada herdeiro a quantia de $352 \$ 979$, valor relativamente pequeno, mas de grande importância afetiva. Ao cabo de suas vidas, nenhum dos dois maiores baleeiros de Itaparica deitou sobre grande fortuna em seu leito de morte. A explicação para isso é que ambos procuraram, na medida do possível, compartilhar o que ganharam com

\footnotetext{
${ }^{48}$ Marcos Cardoso Pimentel faleceu aos 103 anos, em 19 de outubro de 1937. APB - Seção Colonial/Provincial, Inventário de Marcos Cardoso Pimentel. Itaparica, 1946/1949. Doc: 02/796/1222/07.

${ }^{49}$ SANTOS, Deoscoredes M. dos (Mestre Didi). Contos negros da Bahia e contos de Nagô. Salvador: Corrupio, 2003.

${ }^{50}$ APB - Seção Colonial/Provincial. Inventário do africano Marcos Theodoro Pimentel. Itaparica, 1886. Doc: $05 / 2066 / 2587 / 08$.
} 
os seus entes queridos e promoveram a melhoria das condiçóes de vida de parentes, amigos, compadres, filhos, afilhados, além de retiraram do cativeiro seus entes queridos.

Como corolário da sua viagem à África, diferentemente de José Severo Martins Braga, o velho Marcos morreu ostentando o status de africano liberto e assim a sua imagem permaneceu viva na memória de seus descendentes, admiradores e seguidores do culto aos Egun. Sua ascendência africana, portanto, virou motivo de orgulho, símbolo de perseverança e triunfo de um escravizado que virou mito e lenda viva como um dos mais importantes matadores de baleias da Ilha de Itaparica. Interessante como nesse caso a África ganhou duplo significado, e o que para um o esquecimento dela fora requisito essencial para o tratamento distinto nos espaços formais da sociedade dos brancos, para o outro a sua recordação representou o princípio fundamental para afirmação da identidade nagô, africana no seio da sua comunidade.

A baleação foi, assim, um cadinho por meio do qual os libertos encontraram formas de ascensão, sociabilidades e condições de reconstruírem suas vidas após a vida em cativeiro. Marcos Theodoro Pimentel e José Severo Martins Braga foram, com alguma margem de certeza, os grandes responsáveis por urdir essa cadeia de negócios, de família e de amizades entre baleeiros, arpoadores, tanoeiros, embarcadiços, ganhadeiras e escravos em vias de libertação, os quais giravam em sua órbita.

\section{À guisa de conclusão: a metáfora do Mestre Didi}

No conto verídico de um tio africano que virava baleia, Didi, o Mestre das artes, narra uma fascinante fábula que tem como personagem principal um tio africano babalorixá que morava, havia muitos anos, na localidade de Vera Cruz, na Ilha de Itaparica. De acordo com essa lenda, todos os anos, os pescadores da vila de Itaparica, antes de rumarem para as águas da Baía de Todos os Santos atrás dos cetáceos que nadavam livremente pelo golfo, tinham por costume passar na casa daquela figura sagrada a fim de receber as suas bênçãos e assim fazer boas pescarias.

Desse modo, todos os anos, sempre que terminadas as obrigações, o grande babalorixá recomendava aos pescadores que nunca arpoassem a primeira baleia que avistassem, deixando-a passar, e esperassem a aproximação das outras. Certo dia, os embarcadiços, cansados de aguardar dias pela aproximação dos cetáceos, permitiram que o arpoador atirasse o ferro mortal na primeira baleia que avistaram. Enfurecida, a baleia saiu em desespero e esvaneceu nas profundezas do oceano, carregando consigo o arpão lançado pelo arpoador.

Impressionados e amedrontados com o fato, acreditavam terem sido castigados e resolveram voltar ao santuário para falar com o sacerdote a respeito do acontecido. Para a surpresa de todos, ao adentrarem na residência do africano, o encontraram prostrado na 
cama bastante enfermo. A razão para tal fato era que aquele velho sacerdote se transformava, secretamente, em baleia, e o arpáo lançado por aqueles baleeiros ficara cravado mortalmente em suas costas. Como castigo pela desobediência, o velho sussurrou baixinho a seguinte profecia: "De hoje in diante ôces nem ninguém mai vai pegá balêa nu Brazi" ${ }^{51}$

Essa fábula do inteligentíssimo Mestre das artes sugere muitas lucubrações a respeito do tempo da caça de baleia nas águas da Baía de Todos os Santos. Por meio de uma linguagem metafórica, Mestre Didi nos introduz no mundo dos baleeiros e começa por colocar como figura central da peça um africano, talvez uma alusão ao fato de terem sido eles - os africanos - , aqueles que dominaram a arte de matar baleias nos últimos anos dessa atividade no século XIX.

Por sua vez, como uma espécie de tragédia, o desfecho não se constitui em final feliz e há, forçosamente, uma necessidade de se encontrar explicação para o desaparecimento de baleias nas águas da Baía de Todos os Santos. O que a fábula, subjetivamente, nos fala acerca da desobediência dos baleeiros e os seus infortúnios desde então? A própria ação de arpoar a primeira baleia como pecado capital sugere uma leitura acerca da forma indiscriminada como elas eram apresadas em épocas de safras. A despeito de estarem em período de gestação e com filhotes, os arpoadores itaparicanos arremessavam seus ferros cravando-os no dorso das mães e dos seus filhos, sem nenhuma preocupação com a possibilidade de sua extinção. Nadando em bandos, na busca de águas tranquilas e mornas para procriarem, os cetáceos eram geralmente guiados por uma líder, a qual provavelmente já havia comparecido àquela área em períodos de reprodução anterior. Astuciosamente, Mestre Didi, grande conhecedor dos contos dos baleeiros de Itaparica, em mais uma passagem da fábula, avisava aos caçadores de baleia para prestarem atenção às que vinham à frente dos demais mamíferos: "Ocês, mê fio, vai tudo na pai de Deu, Oxum, Emanjá, todo orixá dágua acompanha ocês. Num esquece qui balêa qui vem na frente num mata". ${ }^{52}$

Como foi salientado ao longo do texto, no decorrer das últimas décadas do Oitocentos, as baleias desapareceram e, como profetizou o lendário sacerdote do Mestre Didi nesse interessante conto, dentre outras razóes, o modo predatório como elas eram caçadas foi quase determinante para essa tragédia. Marcos Theodoro Pimentel e José Severo Martins Braga viveram tal momento histórico como sujeitos do seu próprio tempo, sem ter a real dimensão de todo o drama anunciado pela atividade que comandavam. Eles também não viveram o suficiente para presenciar, de modo consternado, o sumiço quase que total dos grandes animais das águas da Baía de Todos os Santos.

Mesmo assim, nas primeiras décadas do século XX, ainda era possível avistar, do deque de uma embarcação a vapor que cruzava as águas da Baía de Todos os Santos, as chaminés das pequenas armaçóes situadas no Manguinho arderem em chamas, enquanto exalavam

\footnotetext{
${ }^{51}$ SANTOS, Deoscoredes M. dos (Mestre Didi), op. cit., p. 63-65.

${ }^{52}$ Ibid.
} 
um forte odor de toucinho de baleia fritando nos tachos de cobre. Lá fora, nos seus arredores, a população pobre disputava com os animais carnívoros os restos dos cetáceos que eram atirados nas areias da velha povoação baleeira do Manguinho. Com certeza, muitos descendentes de Marcos Theodoro Pimentel e de José Severo Martins Braga, participavam, assistiam, negociavam e guardavam fortes lembranças da gloriosa e lendária arte de capturar, com bravura, os grandes leviatãs no pequeno golfo de Todos os Santos.

\section{Referências bibliográficas}

ALENCASTRO, Luiz Felipe de. O trato dos viventes: Formação do Brasil no Atlântico Sul. Séculos XVI e XVII. 4. reimpr. São Paulo: Companhia das Letras, 2000.

BARROS, José Flávio Pessoa; NAPOLEÃO, Eduardo. Ewe òrisá: uso litúrgico e terapêutico dos vegetais nas casas de candomblé jêje-nagô. 4. ed. Rio de Janeiro: Bertrand Brasil, 2009. BETHELL, Leslie. A abolição do comércio brasileiro de escravos. Brasília: Senado Federal, 2002. CALONIUS, Erik. O último navio negreiro da América. Rio de Janeiro: Record, 2008.

CASTELLUCCI JUNIOR, Wellington. Caçadores de baleia: Armaçóes, arpoadores, atravessadores e outros sujeitos envolvidos nos negócios do cetáceo no Brasil. São Paulo: Annablume, 2009.

- Mercando pelo Brasil oitocentista: ganhadeiras, arpoadores e traficantes de derivados de baleias no Recôncavo Baiano (1850-1900). In: LEAL, Maria das Graças de Andrade; MOREIRA, Raimundo Nonato Pereira; CASTELLUCCI JUNIOR, Wellington (Org.). Capitulos de História da Bahia: Novos enfoques, novas abordagens. São Paulo: Annablume, 2009.

- Pescadores e baleeiros: a atividade da pesca da baleia nas últimas décadas do oitocentos. Itaparica: 1860-1888. In: Revista Afro-Ásia. Centro de Estudos Afro-Orientais - Ceao/ UFBA, Salvador, BA, v. 33, p. 133-168, 2005.

- Pescadores e roceiros: Escravos e forros em Itaparica na segunda metade do século XIX. (1860-1888). São Paulo: Annablume, 2008.

CASTILLO, Lisa Earl. Entre memória, mito e História. Viajantes transatlânticos da Casa Branca. In: REIS, João José; AZEVEDO, Elciene (Org.). Escravidão e suas sombras. Salvador: Edufba, 2012.

CONRAD, Robert Edgar. Os últimos anos de escravatura no Brasil: 1850-1888. Rio de Janeiro: Civilização Brasileira, 1978.

. Tumbeiros: o tráfico escravista para o Brasil. São Paulo: Brasiliense, 1985.

ELLIS, Miriam. A baleia no Brasil Colonial. São Paulo: Edusp, 1968. 
ELTIS, David; BEHRENDT, Stephen D.; RICHARDSON, David. A participação dos países da Europa e das Américas no tráfico transatlântico de escravos: novas evidências. Revista Afro-Ásia, Centro de Estudos Afro-Orientais - Ceao/UFBA, Salvador, BA, v. 24, p. 9-50, 2000. ELTIS, David; RICHARDSON, David. Os mercados de escravos africanos recém-chegados às Américas: padróes de preços, 1673-1865. Topoi. Revista de História. Rio de Janeiro, p. 9-46, mar. 2003.

FLORENCE, Afonso Bandeira. Entre o cativeiro e a emancipação: liberdade dos africanos livres no Brasil (1818-1864). Dissertação (Mestrado em História) — Faculdade de Filosofia e Ciências Humanas, Universidade Federal da Bahia, Salvador, 2002.

. Nem escravos, nem libertos: os "africanos livres" na Bahia. Cadernos do Ceas, Salvador, n. 121.

GRAHAN, Richard. Nos tumbeiros mais uma vez? O comércio interprovincial de escravos no Brasil. Revista Afro-Ásia, Centro de Estudos Afro-Orientais - Ceao/UFBA, Salvador, n. 27, p. 121-160, 2002.

GUDEMAN, Stephen; SCHWARTZ. Stuart. Purgando o pecado original: compadrio e batismo de escravos na Bahia do século XVIII. In: REIS, João José (Org.). Escravidão e invenção da liberdade. Estudos sobre o negro no Brasil. São Paulo: Brasiliense, 1988.

HABSBURGO, Maximiliano de. Bahia, 1860: esboço de viagem. Salvador: Fundação Cultural do Estado da Bahia, 1982.

HORNE, Gerald. O sul mais distante: Os Estados Unidos, o Brasil e o tráfico de escravos africanos. São Paulo: Companhia das Letras, 2010.

KARASCH, Mary C. A vida dos escravos no Rio de Janeiro, 1808-1850. São Paulo: Companhia das Letras, 2000.

KLEIN, Herbert S. Novas interpretações do tráfico de escravos do Atlântico. Revista de História da USP, São Paulo, n. 120, p. 3-25, jan./jul. de 1989.

KLEIN, Herbert. O tráfico de escravos no Atlântico. Ribeirão Preto, SP: Funpec, 2004.

KUGLER, Richard C. The penetration of the Pacific. In: CLARK, Joanna Gordon (Org.). Mammals in the Seas. General Papers and Large Cetaceans. Food and agriculture organization of the United Nations. Roma, 1981. v. II.

LARA, Silvia H. (Org.). Ordenaçóes Filipinas, Livro V. São Paulo: Companhia das Letras, 1999. OSÓRIO, Ubaldo. A Ilha de Itaparica: história e tradição. Salvador: Fundação Cultural do Estado da Bahia, 1979. p. 321.

PHILBRICK, Nathaniel. A vingança da baleia: A verdadeira história do baleeiro Essex. São Paulo: Companhia das Letras, 2003.

- Mar de glória: Viagem americana de descobrimento. São Paulo: Companhia das Letras, 2005. 
RODRIGUES, Jaime. O infame comércio: propostas e experiências no final do tráfico de africanos para o Brasil (1808-1859). Campinas, SP: Universidade de Campinas/Cecult, 2000. SANTOS, Deoscoredes M. dos (Mestre Didi). Contos negros da Bahia e contos de Nagô. Salvador: Corrupio, 2003.

SCHWARTZ, Stuart B. Escravos, roceiros e rebeldes. Bauru, SP: Edusc, 2001.

SOARES, Carlos Eugenio Líbano. Instruídos na fé, batizados em pé: Batismo de africanos

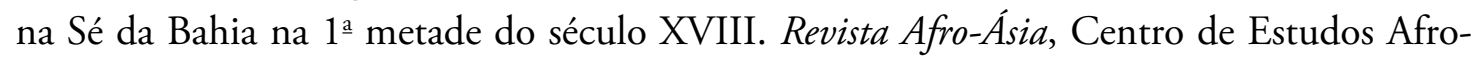
-Orientais - Ceao/UFBA, Salvador, BA, v. 39, p. 79-113, 2010.

- Sacramento ao pé do mar: Batismo de africanos na Freguesia da Conceição da Praia, Bahia. 1700-1751. Revista de História Comparada. Programa de Pós-Graduaçáo em História da Universidade Federal do Rio de Janeiro, Rio de Janeiro, v. 7, n. 2, p. 47-74, dez. 2013.

VERGER, Pierre. Fluxo e refluxo do tráfico de escravos entre o Golfo do Benin e a Babia de Todos os Santos. Salvador: Corrupio, 1987. 